\title{
Construction of climate change scenarios for a tropical monsoon region
}

\author{
L. $\operatorname{Das}^{1,2}$, D. Lohar ${ }^{1, *}$ \\ ${ }^{1}$ Atmospheric Science Research Group, Department of Physics, Jadavpur University, Kolkata 700 032, India \\ ${ }^{2}$ Department of Agricultural Meteorology and Physics, Bidhan Chandra Krishi, Viswavidyalaya, Mohanpur, \\ Nadia 741 252, West Bengal, India
}

\begin{abstract}
Composite seasonal scenarios (per ${ }^{\circ} \mathrm{C}$ change in global equilibrium mean) were developed for the Indian subcontinent for the period 2010-2039 using 5 General Circulation Models (GCMs), namely, HadCM2, CSIRO-MK2b, CGCM1, GFDL-R15 and ECHAM4/OPYC3. These scenarios indicate a general warming over the entire region by about 0.3 to $0.6^{\circ} \mathrm{C}\left( \pm 0.2^{\circ} \mathrm{C}\right)$ with more warming in the northern part and less in the southern part of the country. The study shows pockets of negative and positive changes in rainfall over the study area. Large variations in the estimation of rainfall changes from different models also set the upper and lower limits to more extreme values. Further, scenarios indicate a warming of about $0.4 \pm 0.2^{\circ} \mathrm{C}$ over Gangetic West Bengal (GWB) and surrounding regions in the eastern part of the country. The maximum change in rainfall over this part of the country, according to the scenarios developed, would be $4 \%$. Sub-grid scale seasonal scenarios have been developed over GWB and surrounding regions through statistical downscaling. HadCM2 and ECHAM4/OPYC3 are considered for this purpose, as they more effectively represent spatial and temporal variations in rainfall and temperature over the area. Results reveal more warming $\left(0.3\right.$ to $\left.0.9^{\circ} \mathrm{C}\right)$ and more rainfall changes $(-5$ to $+9 \%)$ than the projections developed without downscaling the GCM output. Further, scenarios developed for the winter and pre-monsoon seasons show unusual changes in rainfall and temperature, which may be due to mesoscale activities present in the study area.
\end{abstract}

KEY WORDS: Statistical downscaling - Composite scenarios · Monsoon - Regional anomalies Resale or republication not permitted without written consent of the publisher

\section{INTRODUCTION}

There is widespread concern that our climate is changing due to gradual increase in greenhouse gases in the atmosphere. As a result, climate change has become one of the most important global environmental challenges with implications for food production, natural ecosystems, fresh water supply, health, etc. A number of studies have attempted to predict changes by mainly using global mean surface temperature and precipitation. Broad-brush predictions at the global scale, or even at hemispheric or continental scale, prove to be of little use, since climate, in particular spatially sensitive parameters like mean temperature and precipitation, varies over distances well below these scales. This was also accepted in the UN
Framework Convention on Climate Change in Rio de Janeiro in 1992, which stressed the need for regional assessment of climate change and its associated impacts. Since then, several studies have been conducted in different regions worldwide, e.g. the Mediterranean basin (Palutikof et al. 1992), east Asia (Hulme et al. 1994), Norway (Benestad 2002) and Scandinavia and new Zealand (Kidson \& Thompson 1998) using General Circulation Models (GCMs). It is generally recognized that GCMs offer the best potential for the development of regional climate change scenarios, but they are unable to give a good reproduction of local climatic conditions (Grotch \& MacCracken 1991). Because of the coarse resolution of GCMs, and an increasing demand from impact analysts for finer resolution in climate change scenarios, 


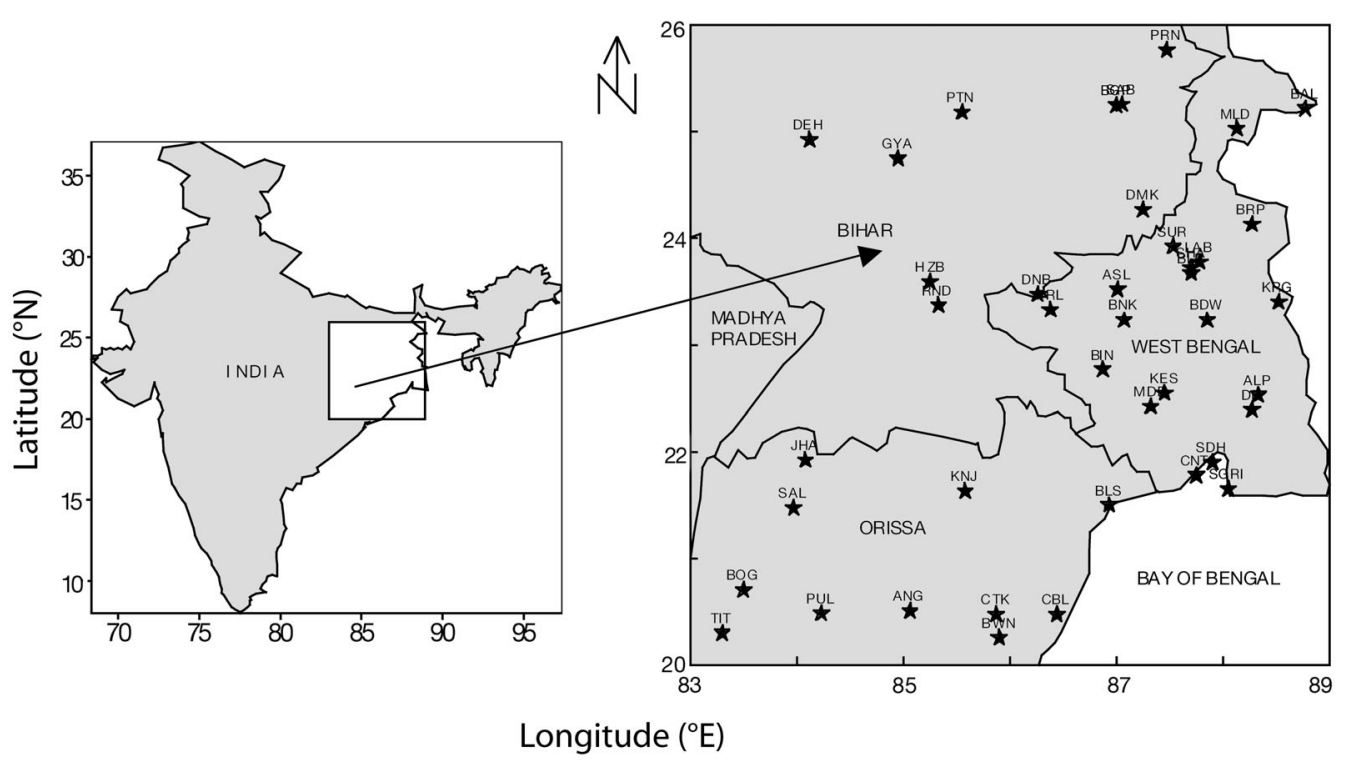

Fig. 1. Location of the study region showing the distribution of observational stations. See Table 2 for station abbreviation explanations

several methodologies to improve resolution have been developed. (e.g. Wilby \& Wigley 1997, Murphy 1998, Wilby et al. 1998). Among the various methodologies, statistical downscaling methods, seeking relationships between the GCM simulated variables and those required by the impact researchers (Kim et al. 1984, Wigley et al. 1990), offer acceptable scenarios (e.g. von Storch et al. 1993, Crane \& Hewitson 1998, Huth \& Kysely 2000).

The Indian economy is primarily agricultural. A large part of the population is therefore engaged in the agricultural sector. In spite of increased grain yields through the 'green revolution', Indian agriculture is still heavily dependent on annual rainfall, and thus vulnerable to climate change. The Indian climate is dominated by 'monsoons', and so monsoon studies have become one of the most important branches of atmospheric research in India. In the context of climate change, there are a variety of studies on the intensity of the monsoon. Instrumental records of monsoon rainfall over the past century have lacked trends at the allIndia scale (Mooley \& Parthasarathy 1984, Kripalani et al. 2003), but significant long-term trends have been found on a smaller scale in various parts of India (Rupa Kumar et al. 1992). It has been shown that rainfall in the coastal region of Gangetic West Bengal (GWB) in the east of India has increased by 10 to $12 \%$ over 100 yr (Rupa Kumar et al. 2002). Instrumental records also indicate a warming of $0.4^{\circ} \mathrm{C}$ over $100 \mathrm{yr}$ in the mean annual surface air temperature for the country as a whole. Seasonal variation shows less warming $\left(0.1^{\circ} \mathrm{C} / 100 \mathrm{yr}\right)$ for the monsoon, and more warming in winter $\left(0.4^{\circ} \mathrm{C} / 100 \mathrm{yr}\right)$ and post-monsoon $\left(0.5^{\circ} \mathrm{C} / 100 \mathrm{yr}\right)$ seasons. Palaeo-climatic simulations correlate increased intensity of the monsoon with increased insolation in the northern hemisphere (Dong et al. 1996). Greenhouse gas warming simulations indicate an increased intensity of Asian summer monsoon (Chakraborty \& Lal 1994, Hirakuchi \& Giorgi 1995) with some exceptions (Lal et al. 1994). Based on various GCM experiments under the combined influence of greenhouse gases and surface aerosols, the third assessment report of the Intergovernmental Panel on Climate Change (IPCC 2001) shows that the climate may warm globally by 1.4 to $5.8^{\circ} \mathrm{C}$ in the next $100 \mathrm{yr}$. Over the Indian sub-continent, the IPCC (2001) predicts that temperature increases will be restricted to $1.4 \pm 0.3^{\circ} \mathrm{C}$ by the $2020 \mathrm{~s}, 2.5 \pm 0.4^{\circ} \mathrm{C}$ by the $2050 \mathrm{~s}$ and $3.8 \pm 0.5^{\circ} \mathrm{C}$ by the $2080 \mathrm{~s}$. The projected increase in precipitation will be limited to $2 \pm 1 \%$ by the 2020 s, $3 \pm$ $1 \%$ by the 2050 s and $7 \pm 3 \%$ by the 2080 s (IPCC 2001). Due to limited understanding of critical processes in the climatic system, the existence of multiple climatic and non-climatic systems, regional-scale variations and non-linearity, there is a high degree of uncertainty among predictions of the impact of climate change. In another study (Rupa Kumar et al. 2002), climatic scenarios for India for the periods 1980-2039 and 1920-1979 were compared using ECHAM4 and HadCM2. ECHAM4 indicated an increase in monsoon rainfall of $13 \%$, while HadCM2 showed a $6 \%$ reduction; for both models the mean annual temperature increased by about $1.0^{\circ} \mathrm{C}$. Seasonal variation shows more warming in winter and pre-monsoon seasons. However, there are no all-India or more local-scale seasonal composite scenarios, either derived directly 
from the GCMs outputs or using some kind of downscaling method for finer resolution, available in the literature.

There were 2 main aims for the present study. Firstly, to produce seasonal composite scenarios for the Indian subcontinent as a whole using multiple GCMs. Secondly, to construct detailed scenarios of a part of the Indian subcontinent, i.e. GWB and surrounding regions (Fig. 1), using a statistical downscaling technique, in order to further elucidate the study .

\section{DATA AND STUDY AREA}

Five GCMs were selected, namely ECHAM4/ OPYC3, HadCM2, GFDL-R15, CGCM1 and CSIRO$\mathrm{Mk} 2 \mathrm{~b}$. The general characteristics of these models have been displayed in Table 1. As a preliminary step, the monthly mean temperature and monthly rainfall data sets for 'IS92a' emission scenarios were collected from the IPCC data distribution centre for the periods 1961-1990 and 2010-2039. Observational records of monthly mean temperature and rainfall for all available stations within GWB and surrounding regions were collected for the period 1961-2000 from the India Meteorological Department (IMD) and the Agriculture Department of West Bengal. Data from stations with the required length of record were retained. Details of the stations are given in the Table 2 .

Part of the present study covers the entire Indian subcontinent, however, emphasis has been given over GWB and surrounding regions (20 to $26^{\circ} \mathrm{N}$ and 83 to $89^{\circ} \mathrm{E}$ ) in the eastern India (Fig. 1). The climate over this part of the country is divided into 4 seasons. The seasons are described as winter (DecemberJanuary-February, DJF), pre-monsoon (March-AprilMay, MAM), monsoon (June through September, JJAS) and post-monsoon (October-November, ON). The coolest season is winter when the mean tempera-
Table 2. List of observational stations used in the study

\begin{tabular}{|llccr|}
\hline Station & $\begin{array}{c}\text { Abbrevi- } \\
\text { ation }\end{array}$ & $\begin{array}{c}\text { Latitude } \\
\left({ }^{\circ} \mathrm{N}\right)\end{array}$ & $\begin{array}{c}\text { Longitude } \\
\left({ }^{\circ} \mathrm{E}\right)\end{array}$ & $\begin{array}{r}\text { Altitude } \\
(\mathrm{m})\end{array}$ \\
\hline Alipore & ALP & 22.53 & 88.33 & 6.0 \\
Angul & ANG & 20.50 & 85.06 & 58.2 \\
Asansole & ASL & 23.52 & 87.01 & 102.0 \\
Balasore & BLS & 21.50 & 86.93 & 20.3 \\
Bankura & BNK & 23.23 & 87.07 & 48.0 \\
Berhampore & BRP & 24.13 & 88.27 & 19.0 \\
Bhubhaneswar & BWN & 20.25 & 85.90 & 46.0 \\
Bhagolpur & BGP & 25.25 & 87.00 & 68.0 \\
Burdwan & BDW & 23.23 & 87.85 & 10.4 \\
Balurghat & BAL & 25.22 & 88.77 & 9.0 \\
Bolangir & BOG & 20.70 & 83.50 & 602.0 \\
Bolpur & BLP & 23.67 & 87.70 & 46.0 \\
Chandbali & CBL & 20.47 & 86.44 & 6.7 \\
Contai & CNT & 21.78 & 87.75 & 11.0 \\
Cuttack & CTK & 20.47 & 85.87 & 49.0 \\
DumDum & DD & 22.39 & 88.27 & 6.2 \\
Binpur & BIN & 22.77 & 86.87 & 49.0 \\
Dumka & DMK & 24.27 & 87.25 & 149.4 \\
Dhanbad & DNB & 23.47 & 86.26 & 257.0 \\
Dehri & DEH & 24.92 & 84.12 & 202.0 \\
Gaya & GYA & 24.75 & 84.95 & 116.0 \\
Jharsugada & JHA & 21.92 & 84.08 & 230.0 \\
Keonjhar & KNJ & 21.63 & 85.58 & 432.8 \\
Krishnanagar & KRG & 23.40 & 88.52 & 15.0 \\
Labpur & LAB & 23.78 & 87.78 & 44.0 \\
Hajaribugh & HZB & 23.59 & 85.25 & 611.0 \\
Keshpur & KES & 22.55 & 87.45 & 47.0 \\
Malda & MLD & 25.03 & 88.13 & 9.0 \\
Midnapur & MDP & 22.42 & 87.32 & 45.3 \\
Purulia & PRL & 23.33 & 86.38 & 262.0 \\
Purnea & PRN & 25.77 & 87.47 & 38.0 \\
Phulbani & PUL & 20.48 & 84.23 & 274.0 \\
Patna & PTN & 25.18 & 85.55 & 60.2 \\
Sagar Island & SGR & 21.65 & 88.05 & 3.0 \\
Sandhead & SDH & 21.90 & 87.90 & 10.0 \\
Shantiniketan & SHA & 23.72 & 87.70 & 49.0 \\
Sambalpur & SAL & 21.47 & 83.97 & 148.0 \\
Suri & SUR & 23.92 & 87.53 & 52.0 \\
Sabour & SAB & 25.26 & 87.05 & 8.0 \\
Titlagargh & TIT & 20.30 & 83.30 & 211.7 \\
Ranchi & RND & 23.37 & 85.33 & 600.0 \\
\hline
\end{tabular}

Table 1. General characteristic features of the GCMs. Resolution: horizontal resolution (long. $\times$ lat.). Temp: equilibrium temperature is global mean change under double $\mathrm{CO}_{2}$. Elevation: model output (temperature) from the surface. Emission scenario: IS92a data sets from IPCC data distribution centre for 1961-1990 and 2010-2039

\begin{tabular}{|lcccc|}
\hline & Resolution & $\begin{array}{c}\text { Temp. } \\
\left({ }^{\circ} \mathrm{C}\right)\end{array}$ & Elevation & $\begin{array}{c}\text { Emission } \\
\text { scenarios }\end{array}$ \\
\hline ECHAM4/OPYC3 & $2.8^{\circ} \times 2.8^{\circ}$ & 2.6 & $0 \mathrm{~m}$ & EEGGA1 \\
HadCM2 & $3.75^{\circ} \times 2.5^{\circ}$ & 2.5 & $1.5 \mathrm{~m}$ & HHGGA1 \\
GFDL-R15 & $7.5^{\circ} \times 4.5^{\circ}$ & 3.7 & $\mathrm{a}$ & GGGGA1 \\
CGCM1 & $3.75^{\circ} \times 3.75^{\circ}$ & 3.5 & $\mathrm{~b}$ & CCGGA1 \\
CSIRO-MK2b & $5.62^{\circ} \times 3.21^{\circ}$ & 4.3 & $2.0 \mathrm{~m}$ & AAGGA1 \\
a Sigma 0.99 level & & & & \\
bScreen level & & & & \\
\hline
\end{tabular}

ture is around $16^{\circ} \mathrm{C}$. Occasionally, the area experiences the impact of western disturbances through the formation of induced low-pressure areas, resulting in a small amount of rainfall during this winter season. Mean rainfall amounts to only $35 \mathrm{~mm}$ in this season. The Pre-monsoon is the hot season when the mean maximum temperatures typically exceed $38^{\circ} \mathrm{C}$, but are modulated by thunderstorm activities (Sadhukhan et al. 2000), which help bring the average rainfall to $185 \mathrm{~mm}$. Climatologically, the area is located in the tropical monsoon 
Table 3. Changes in rainfall $(\%)$ and temperature $\left({ }^{\circ} \mathrm{C}\right)$ during the period $2010-2039$ over the all-India region, with respect to the 1961-1990 baseline period

\begin{tabular}{|lcccccccc|}
\hline & \multicolumn{4}{c}{ Rainfall (\%) } & & \multicolumn{3}{c|}{ Temperature $\left({ }^{\circ} \mathrm{C}\right)$} \\
& Winter & Pre-monsoon & Monsoon & Post-monsoon & Winter & Pre-monsoon & Monsoon Post-monsoon \\
\hline ECHAM4 & -6 to +12 & -10 to +10 & -2 to +14 & -4 to +20 & 0.4 to 1.1 & 0.4 to 0.9 & 0.2 to 0.9 & 0.4 to 1.0 \\
HadCM2 & -15 to +15 & -25 to +35 & -18 to +2 & -14 to +6 & 0.5 to 0.7 & 0.3 to 0.7 & 0.5 to 1.0 & 0.7 to 0.9 \\
GFDL-R15 & -2 to +6 & -2 to +14 & -2 to +7 & -1 to +8 & 0.2 to 0.5 & 0.3 to 0.5 & 0.1 to 0.4 & 0.2 to 0.6 \\
CGCM1 & -2 to +8 & -5 to +6 & -8 to +18 & -6 to +6 & 0.2 to 0.7 & 0.1 to 0.8 & 0.1 to 0.8 & 0.1 to 0.7 \\
CSIRO-MK2b & -7 to +11 & -2 to +12 & -6 to +6 & -3 to +2 & 0.2 to 0.4 & 0.1 to 0.4 & 0.2 to 0.4 & 0.1 to 0.5 \\
\hline
\end{tabular}

region. The GWB region lies in the moist end of the monsoon trough, and a number of depressions cross through it, resulting heavy rainfall over the area. The region receives an average of $1145 \mathrm{~mm}$ of rainfall during the monsoon season. Tropical cyclones mostly form in the post-monsoon season over the Bay of Bengal, and cross through the area bringing heavy showers. However, average rainfall in this season is only $150 \mathrm{~mm}$, since cyclones are relatively infrequent.

\section{ALL INDIA SCENARIOS FOR 2010-2039}

There has been increasing pressure, particularly from impact analysts, to develop future climatic scenarios. As no model can simulate either the current climate or future projections in a consistent manner that represents the fine structure of the spatial distribution of the atmospheric variables, composite scenarios using several models are more acceptable (Palutikof et al. 1992). An attempt has been made in the present study to construct all-India composite seasonal temperature and rainfall change scenarios for 2010-2039, using all the 5 GCMs.

\subsection{Temperature change scenarios}

The output of each GCM was interpolated to a common grid of resolution $2.5^{\circ}$ latitude $\times 2.5^{\circ}$ longitude, as the GCMs differ in their horizontal resolutions. Following this, the seasonal temperature changes were calculated by taking the difference, at each grid point, between the 2010-2039 values and the 1961-1990 baseline values. Since different models have different equilibrium temperature changes under doubled $\mathrm{CO}_{2}$, changes at the grid points were calculated per ${ }^{\circ} \mathrm{C}$ change in global mean temperature following Palutikof et al. (1992). A range of values for each model is given in the Table 3. Finally, composite seasonal temperature change scenarios were constructed using:

$$
\Delta \bar{T}=\frac{1}{n} \sum_{i=1}^{n} \Delta T_{i}
$$

where $n$ is the number of models, $\Delta \bar{T}$ is the mean of $\Delta T$ and $\Delta T_{i}$ is the seasonal temperature change for the $i$ th model. In order to access the reliability of the standardized pattern of change, an upper and a lower limit, $t_{\mathrm{u}}$ and $t_{1}$, were placed on the scenarios (Fig. 2). The limits are calculated using:

$$
\begin{aligned}
& t_{\mathrm{u}}=\Delta \bar{T}+1.64 \mathrm{~s} \\
& t_{1}=\Delta \bar{T}-1.64 \mathrm{~s}
\end{aligned}
$$

where $s$ is the standard deviation.

The seasonal temperature change scenarios reveal that there is a warming all over the Indian subcontinent. An estimation of about 0.3 to $0.6^{\circ} \mathrm{C}\left( \pm 0.2^{\circ} \mathrm{C}\right)$ per ${ }^{\circ} \mathrm{C}$ global change is noticed with a maximum in northern India and a minimum in southern India. Henceforth all the changes are expressed per ${ }^{\circ} \mathrm{C}$ global change throughout the text. It has been noted that the pattern is more or less the same in all the seasons. The minimum change in mean temperature remains the same as that in the monsoon season $\left(0.3^{\circ} \mathrm{C}\right)$, while the maximum change in temperature varies slightly in the other seasons.

\subsection{Rainfall change scenarios}

Unlike the temperature change scenarios, the projected rainfall changes were expressed as a percentage of baseline rainfall for each model. The percentage change in rainfall is then divided by the equilibrium temperature change for the corresponding model. Unlike warming all over the Indian region, estimation of rainfall changes indicates pockets of enhanced and deficient rainfall in various parts of the country (Table 3). The results from these 5 models were used to construct composite seasonal scenarios (Fig. 3) with an upper and a lower limit, $p_{\mathrm{u}}$ and $p_{1}$, similar to that in the temperature change scenarios. In the winter season, the model average rainfall change 
(a) DJF (winter)

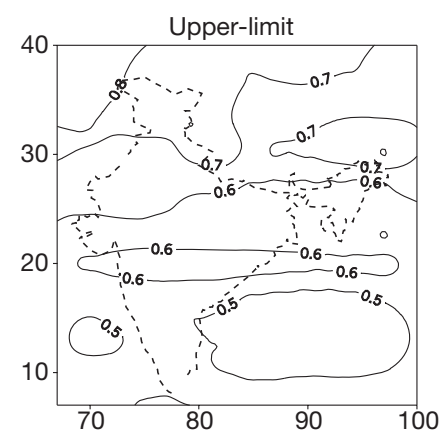

(b) MAM (pre-monsoon)

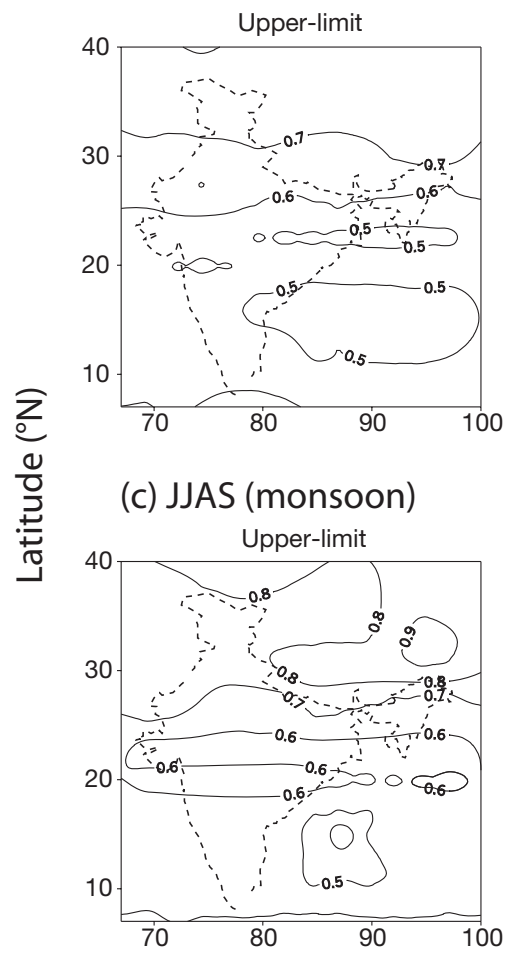

(d) ON (post-monsoon)

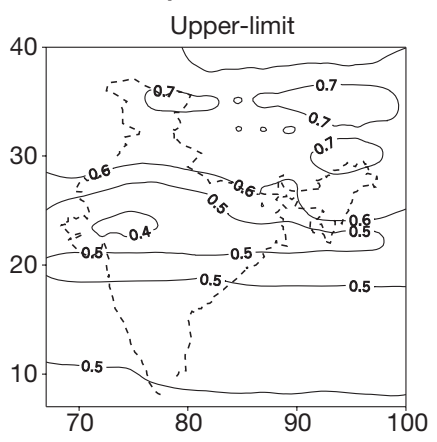

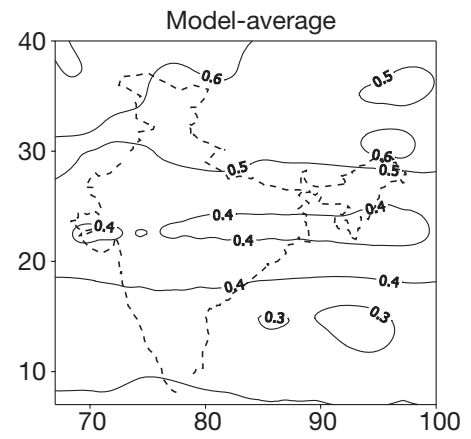
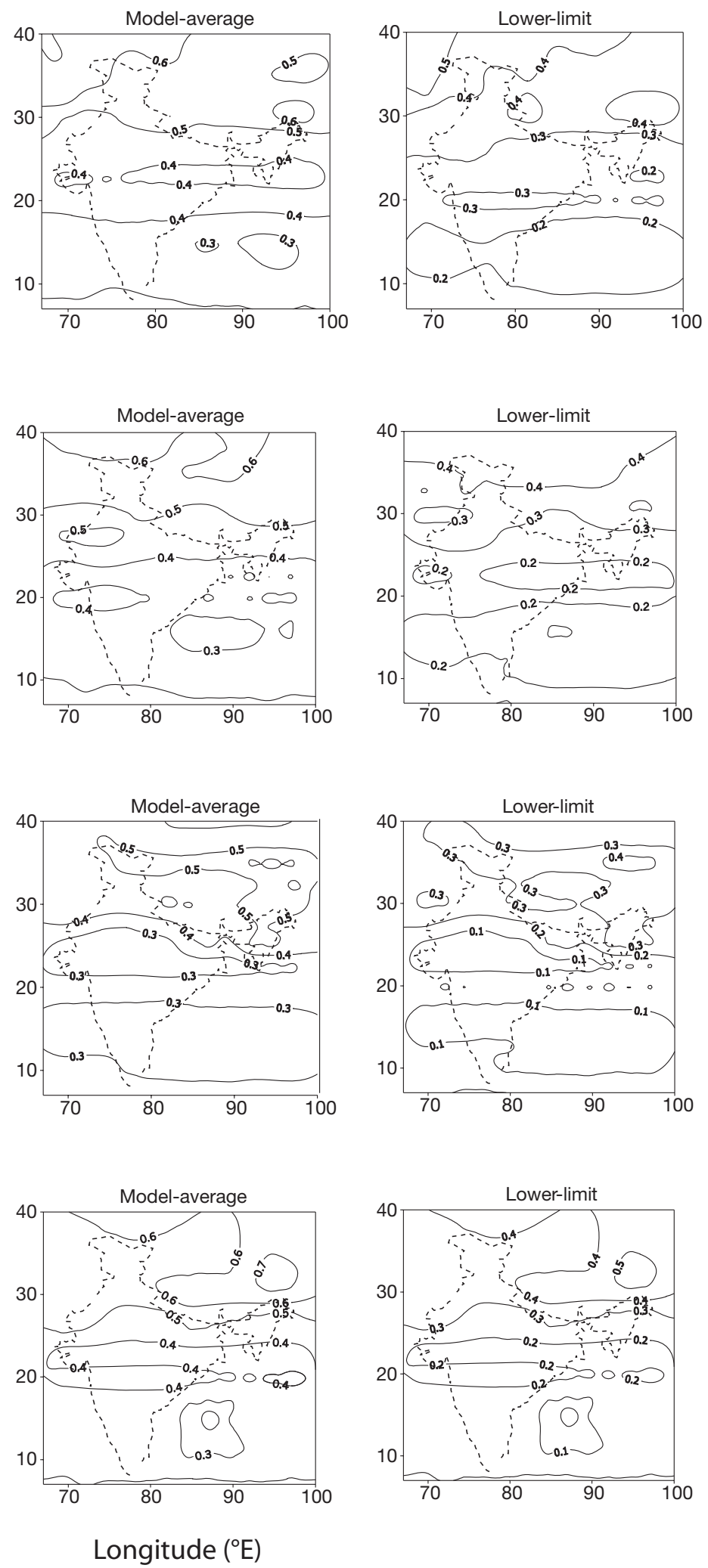

Fig. 2. Estimated mean seasonal temperature change $\left({ }^{\circ} \mathrm{C}\right)$ with an upper and a lower limits for the period 2010-2039 with respect to the 1961-1990 baseline. DJF: December-January-February; MAM: March-April-May; JJAS: June through to September; ON: October-November 
(a) DJF (winter)

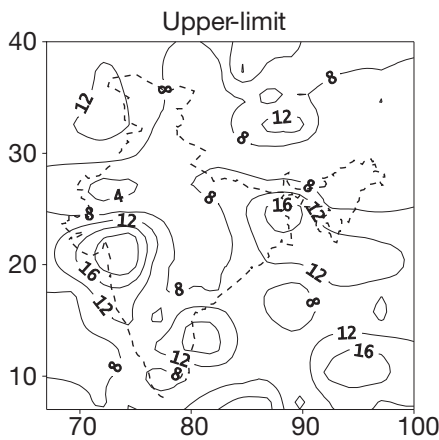

(b) MAM (pre-monsoon)

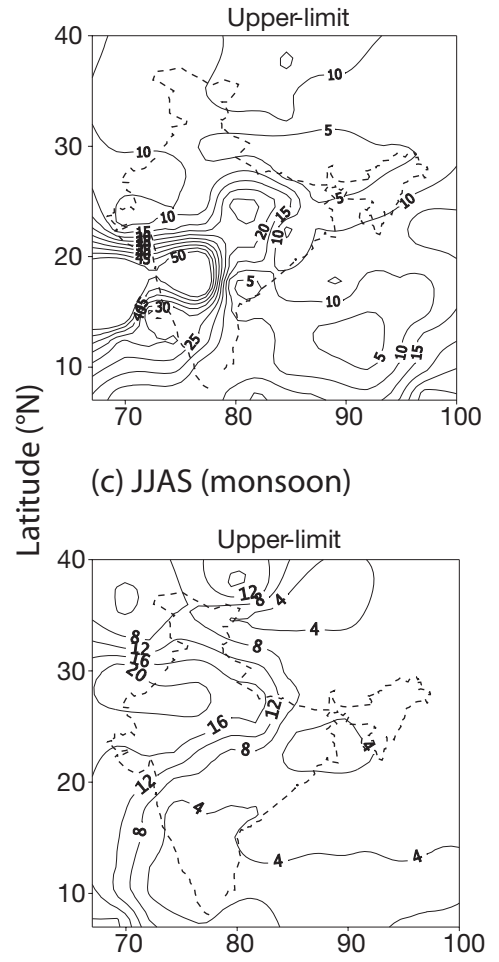

(d) ON (post-monsoon)

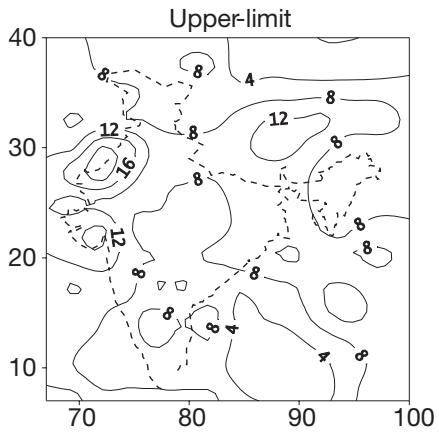

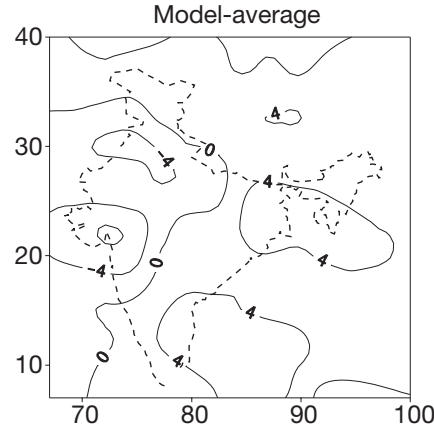
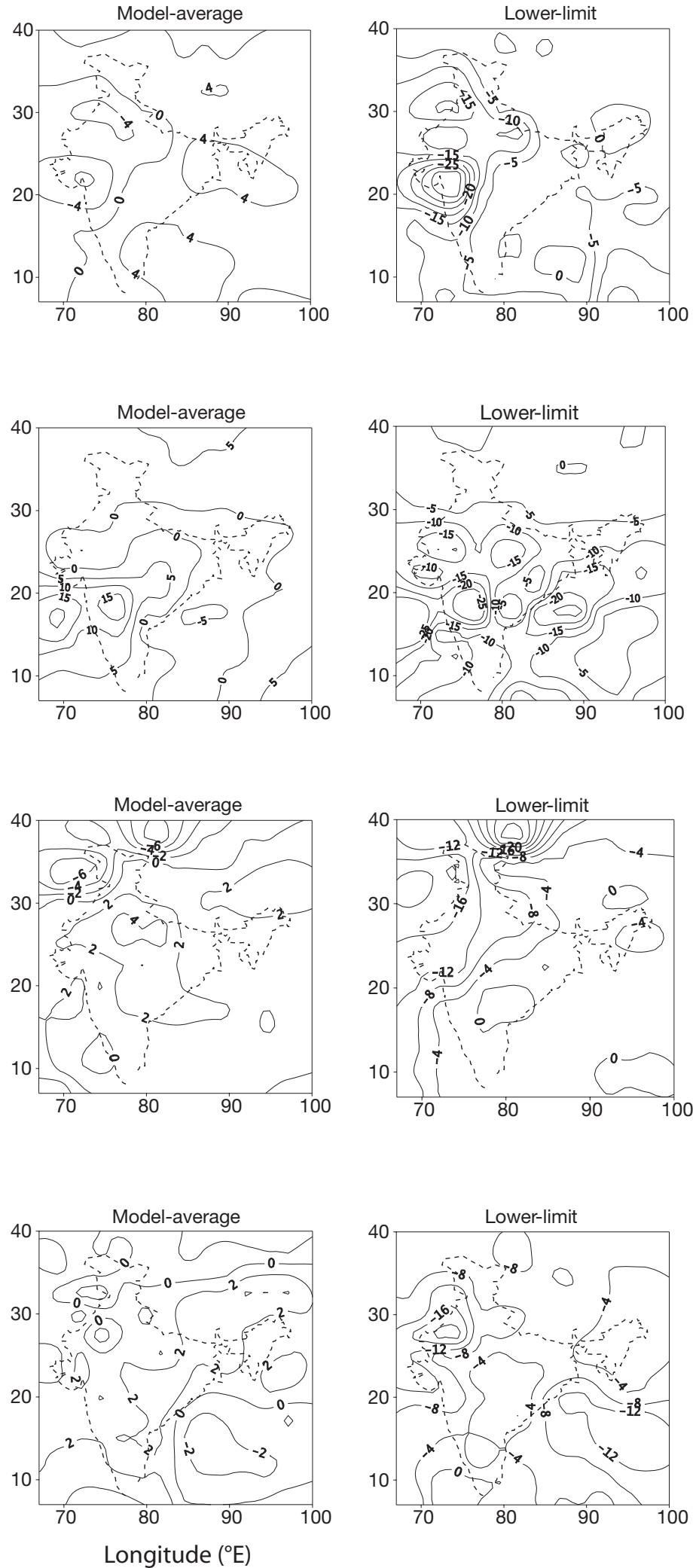

Fig. 3. Estimated mean seasonal rainfall change (\%) with upper and lower limits for the period 2010-2039 with respect to the 1961-1990 baseline 
varies from -4 to $+4 \%$, showing a reduction over the NW part and an increase over the GWB region. In the pre-monsoon season, the results show western India experiencing the greatest change $(+10 \%)$, while the east and northeast show insignificant changes in rainfall. The change over central India in the monsoon season is $+2 \%$, while a reduction in rainfall is seen over the NW part of the country. In the post-monsoon season, the change in rainfall is between -2 and $+2 \%$ all over the country.

\section{MODEL VALIDATION}

The main focus of the present work is the projection of climate change scenarios during the period 2010-2039 over the eastern part of India, i.e. over GWB and surrounding regions. All the abovementioned GCMs may not be suitable considering their grid point location within the region of interest, and also with regard to their ability to represent the spatio-temporal pattern of the atmospheric variables. Thus, it was essential to validate the models before developing the scenarios. This was done through the comparison of the GCMs simulated baseline values with the observational values for seasonal cycles of rainfall and mean temperature. In order to check the degree of agreement of the spatial patterns between the modeled and the observed values, the spatial correlations were also calculated.

\subsection{Seasonal cycles of rainfall and temperature}

Observational stations were identified which lay within a $5^{\circ} \times 5^{\circ}$ grid box centered on the respective model grid location. Area-average monthly rainfall was calculated using those identified stations corresponding to each model and compared with the model output (Fig. 4). Being a tropical monsoon region, the study area has a pronounced and distinctive seasonal cycle of rainfall with very high rainfall during the monsoon season. A second peak was also observed during the pre-monsoon period. To some extent all the models simulate the monsoon season rainfall better than the other seasons. ECHAM4 seems to simulate the observed seasonal cycle better while the others fail particularly for the winter and pre-monsoon seasons. Monthly mean temperatures were also calculated using the identified stations and a comparison was made with the modeled values (Fig. 5). ECHAM4 and HadCM2 represent the seasonal cycle of mean temperature more effectively than the other models. Student's $t$-test using model output and observations at $10 \%$ significant level $(\alpha=0.1)$ also suggests that
ECHAM4 and HadCM2 model outputs are reasonably representative of the study area.

\subsection{Spatial correlation}

Correlation coefficients were calculated between the observed and the modeled values of seasonal rainfall and mean temperature for all the 5 models and are given in the Table 4. Each model under consideration shows a better correlation coefficient for temperature irrespective of the seasons. However, no model shows higher correlation for rainfall in all the seasons, rather correlation coefficients are low irrespective of the seasons. This indicates the limitation of the models for representing the spatial variation of rainfall. Despite this limitation, the other aspects of the models, such as horizontal resolutions, the location of the model grid points with respect to the study region, high correlation coefficients for temperature and the ability to represent the seasonal cycle of rainfall, indicate that HadCM2 and ECHAM4 are the most appropriate models for the generation of sub-grid scale scenarios.

\section{SUB-GRID SCALE SCENARIOS}

The usefulness of the scenarios developed directly from GCM output and interpolated to a common grid is constrained by the coarse resolution of the models, and is currently limited to a horizontal resolution of about $300 \mathrm{~km}$ (e.g. Johns et al. 1997). Results from the GCMs are the primary source of information for assessment of future impacts of climate change. However, in many cases information is required on a network of point locations (Robinson \& Finkelstein 1991), implying the need for a suitable 'downscaling' procedure. This is particularly true when the model results are required for the application of agricultural crop models (e.g. Mearns et al. 1997). In the present study, sub-grid scale scenarios were developed for GWB and surrounding regions using a statistical downscaling method as explained in the following sub-section. HadCM2 and ECHAM4 were used for this purpose, as they appear to be the most suitable models for the study region.

\subsection{Methodology}

Time series data sets of observed monthly mean temperature and monthly rainfall within the study area were formed for the period 1961-2000. The data series spanning the period 1961-1990 were used for the construction of statistical models while the rest, i.e. data for the period 1991-2000, was used for validation of the 
constructed models. The temperature anomalies at each station, $A t_{i j}$, were calculated using $A t_{i j}=t_{i j}-T_{j}$, where $t_{i j}$ is the mean monthly temperature for the $i$ th year and $j$ th month while $T_{j}$ is the long-term mean monthly temperature for the $j$ th month. Similarly, the rainfall anomalies, $A p_{i j}$, were also calculated using $A p_{i j}$ $=p_{i j}-P_{j}$, where $p_{i j}$ is the mean monthly rainfall for the ith year and $j$ th month while $P_{j}$ represents the longterm mean monthly rainfall for the $j$ th month. The individual station anomalies were then used to calculate regionally averaged anomalies (Palutikof et al. 1992, Palutikof \& Wigley 1996). For temperature, the regional anomaly for each station was calculated by taking all stations within a $5^{\circ} \times 5^{\circ}$ grid box, with the station in question as the center of the grid box. For rainfall, area weighted values were used due to the substantial degree of spatial variability, and the regional anomalies were calculated following the same procedure as with temperature. In both cases, the station of interest was excluded in the calculation of regional anomalies. Finally, data sets were compiled for regional anomaly and station anomaly of mean monthly temperature and rainfall corresponding to each station. Regression analyses were then carried out, using station temperature and rainfall anomalies as predictands, and their corresponding regionally averaged anomalies as predictors. The analyses were performed on a seasonal basis; thus for each station in the analysis, 8 regression equations were formed, as there are 4 seasons. With the assumption that GCM grid-point temperature and rain-
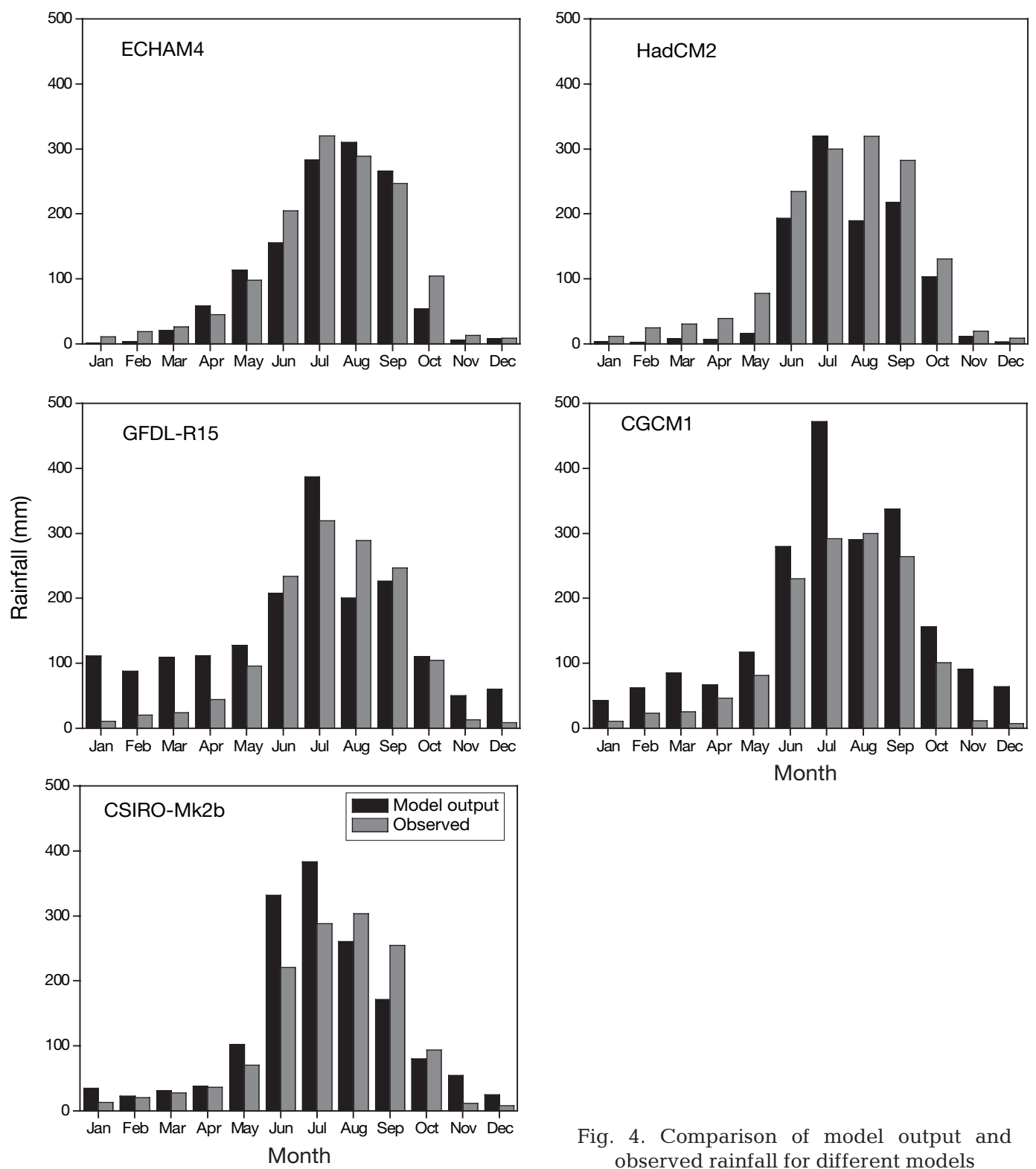

Fig. 4. Comparison of model output and observed rainfall for different models 
fall values were equivalent to regionally averaged values, the GCM results were interpolated from the model grid to the station locations for each model and substituted in the regression equations as predictors. The
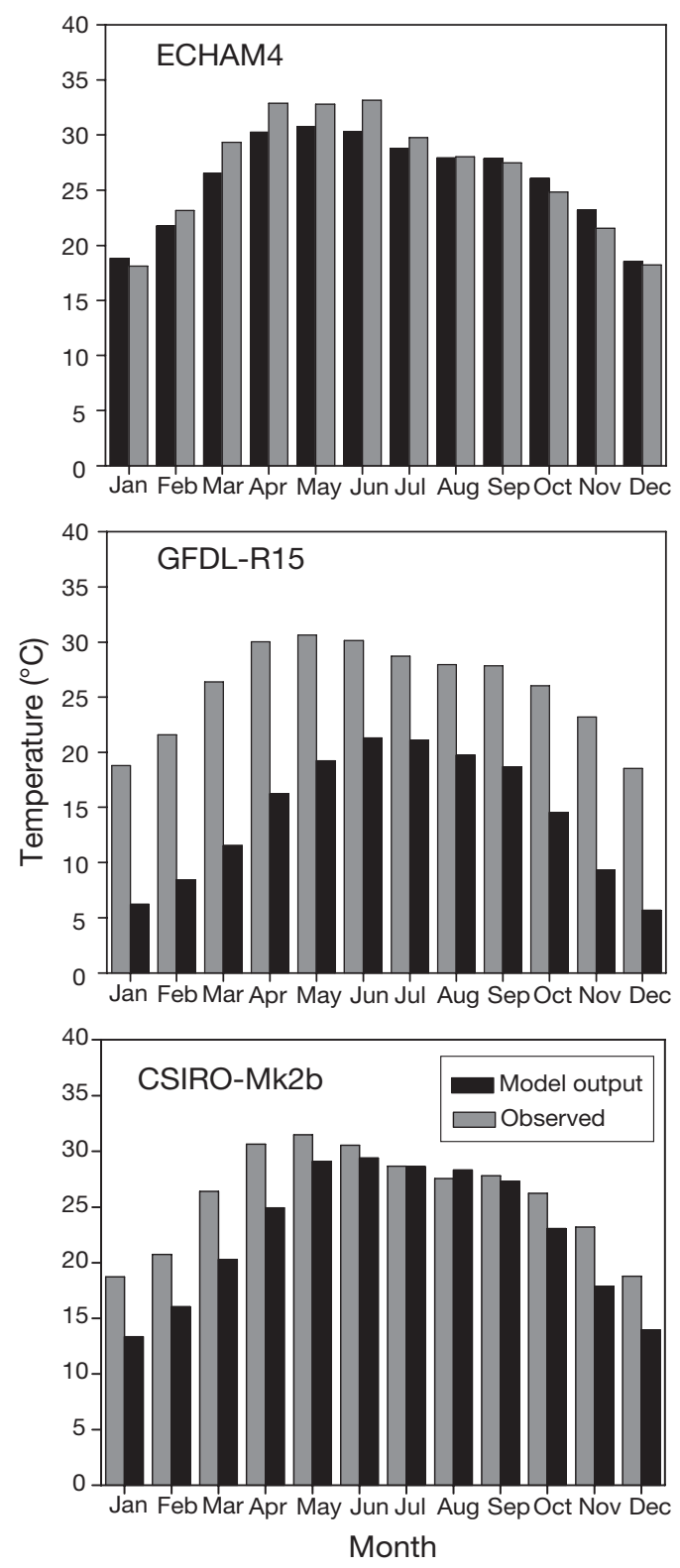

predicted change in temperature was then divided by the corresponding global mean equilibrium temperature change for both models and finally an average was taken in order to obtain composite scenarios.
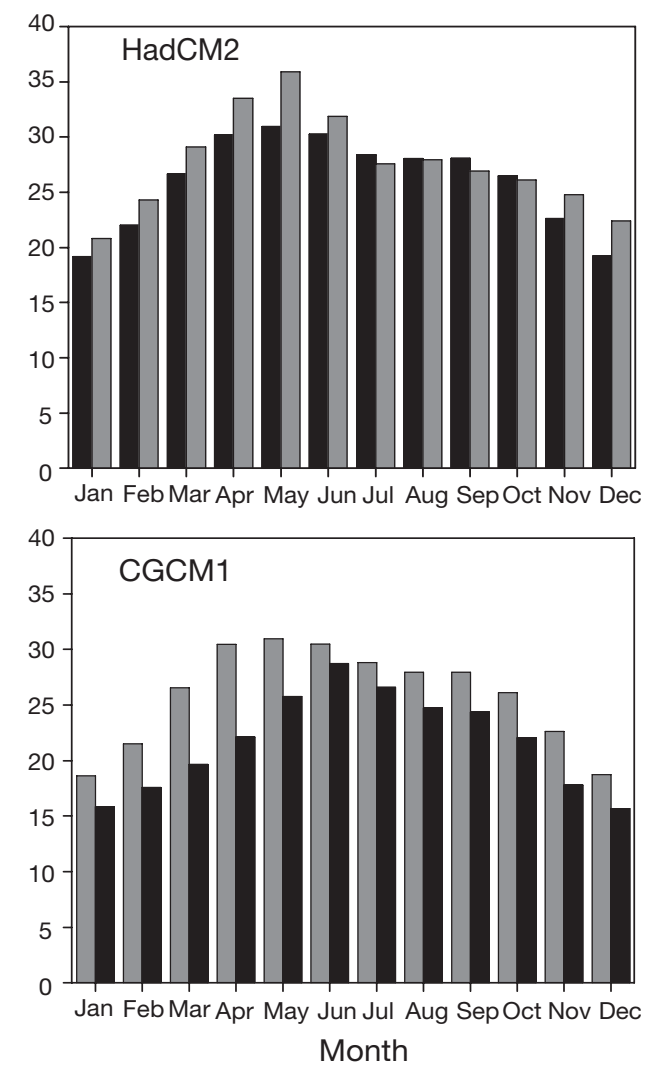

Fig. 5. Comparison of model output and observed mean temperature for different models

Table 4. Spatial correlation coefficients between GCM control runs and observed precipitation

\begin{tabular}{|lcccccccc|}
\hline & \multicolumn{4}{c}{ Rainfall } & & \multicolumn{3}{c|}{ Temperature } \\
& Winter & Pre-monsoon & Monsoon & Post-monsoon & Winter & Pre-monsoon & Monsoon Post-monsoon \\
\hline ECHAM4 & 0.26 & 0.17 & 0.37 & 0.34 & 0.54 & 0.08 & 0.12 & 0.33 \\
HadCM2 & 0.22 & 0.28 & 0.56 & 0.77 & 0.58 & 0.46 & 0.46 & 0.17 \\
GFDL-R15 & 0.12 & 0.002 & 0.41 & 0.16 & 0.71 & 0.62 & 0.43 & 0.20 \\
CGCM1 & 0.54 & 0.07 & 0.65 & 0.28 & 0.74 & 0.62 & 0.42 & 0.38 \\
CSIRO-MK2b & 0.22 & 0.30 & 0.30 & 0.39 & 0.77 & 0.60 & 0.44 & 0.38 \\
\hline
\end{tabular}




\subsection{Testing the performance of the regression equations}

If the regression equations are to be an effective tool, the predictor variable must explain a high proportion of the variance (as measured by the square of the

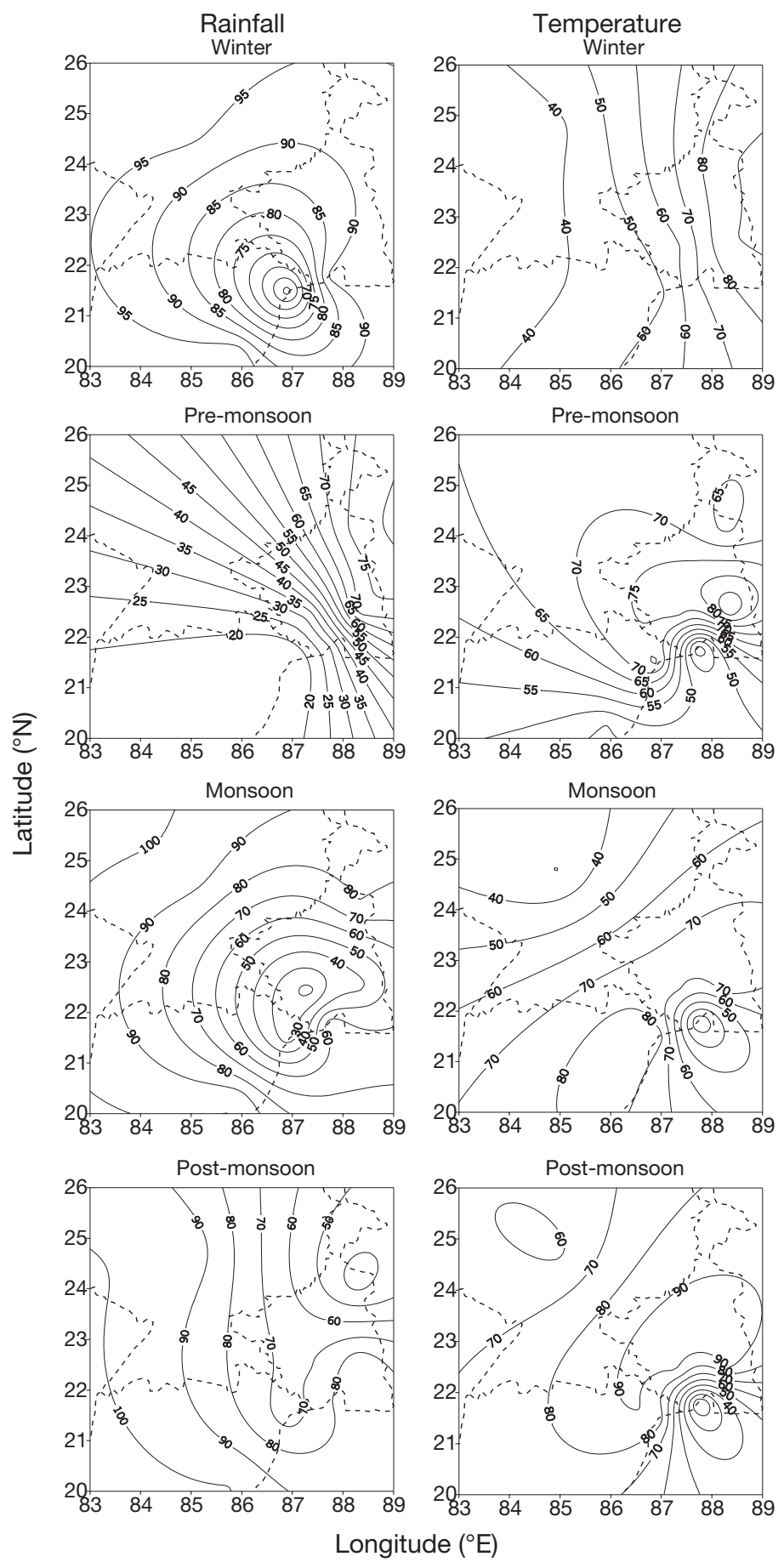

Fig. 6. Variance explained (\%) by the 2-predictor variable regression equation estimating seasonal rainfall and temperature of various stations for the period 1991-2000 correlation coefficient) in the predicted variable both during calibration and validation. The spatial patterns of variance (\%) explained during the validation period (1991-2000) are shown in Fig. 6.

The performance of the regression equations is better in the case of rainfall over the entire study area in all the seasons except for the pre-monsoon season (Table 5). On the other hand, variance explained by the regression equations in the case of temperature is more than $50 \%$ in larger areas except for the winter season. So, future projection of mean temperature and rainfall using these regression equations may be more reliable for most parts of the study area.

\subsection{Rainfall scenarios for 2010-2039}

The projected seasonal rainfall scenarios based on the above regression equations are shown in Fig. 7. Maximum change in rainfall is seen in the winter season for both the models (HadCM2 and ECHAM4). The values range from 10 to $25 \%$ for HadCM2 and from 5 to $35 \%$ for ECHAM4. The pattern indicates a maximum over the coast of the Bay of Bengal and gradually decreases inland for HadCM2, while the opposite is the case for ECHAM4. In the pre-monsoon season, negative changes in rainfall are seen throughout the study region for HadCM2, with a maximum over the coastal region $(-13 \%)$, while slightly positive changes are seen for ECHAM4 (1 to $6 \%$ ). It is noteworthy that the changes are lowest in the monsoon season $(-2$ to $0 \%$ for HadCM2 and 1 to $5 \%$ for ECHAM4). A variation of -13 to $+5 \%$ in case of HadCM2 occurs in the post-monsoon season, while variation is greater ( 7 to $17 \%)$ in ECHAM4.

\subsection{Temperature scenarios for 2010-2039}

The projected seasonal temperature change scenarios have been developed in a similar way to rainfall scenarios, and are shown in Fig. 8. There is a warming in the range of 0.3 to $0.7^{\circ} \mathrm{C}$ in the seasons all over the

Table 5. Seasonal variance calculated by regression equations

\begin{tabular}{|lcc|}
\hline \multirow{2}{*}{ Seasons } & \multicolumn{2}{c|}{ Variance (\%) } \\
& Temperature & Rainfall \\
\hline Winter & $40-95$ & $70-95$ \\
Pre-monsoon & $50-80$ & $20-75$ \\
Monsoon & $40-80$ & $30-100$ \\
Post-monsoon & $40-90$ & $40-100$ \\
\hline
\end{tabular}


area except for the monsoon season for HadCM2. In the latter case, there is a warming of more than $1^{\circ} \mathrm{C}$ in the NW part of the study area. The spatial distribution shows more change in the eastern and NW part of the study region for both the models. In the pre-monsoon season, changes are between 0.3 to $0.6^{\circ} \mathrm{C}$ with less value over the coastal belt for ECHAM4. HadCM2 indicates a variation of about 0.4 to $0.7^{\circ} \mathrm{C}$ with a maximum over the central part of the study area. In the monsoon season, HadCM2 shows a variation of 0.3 to
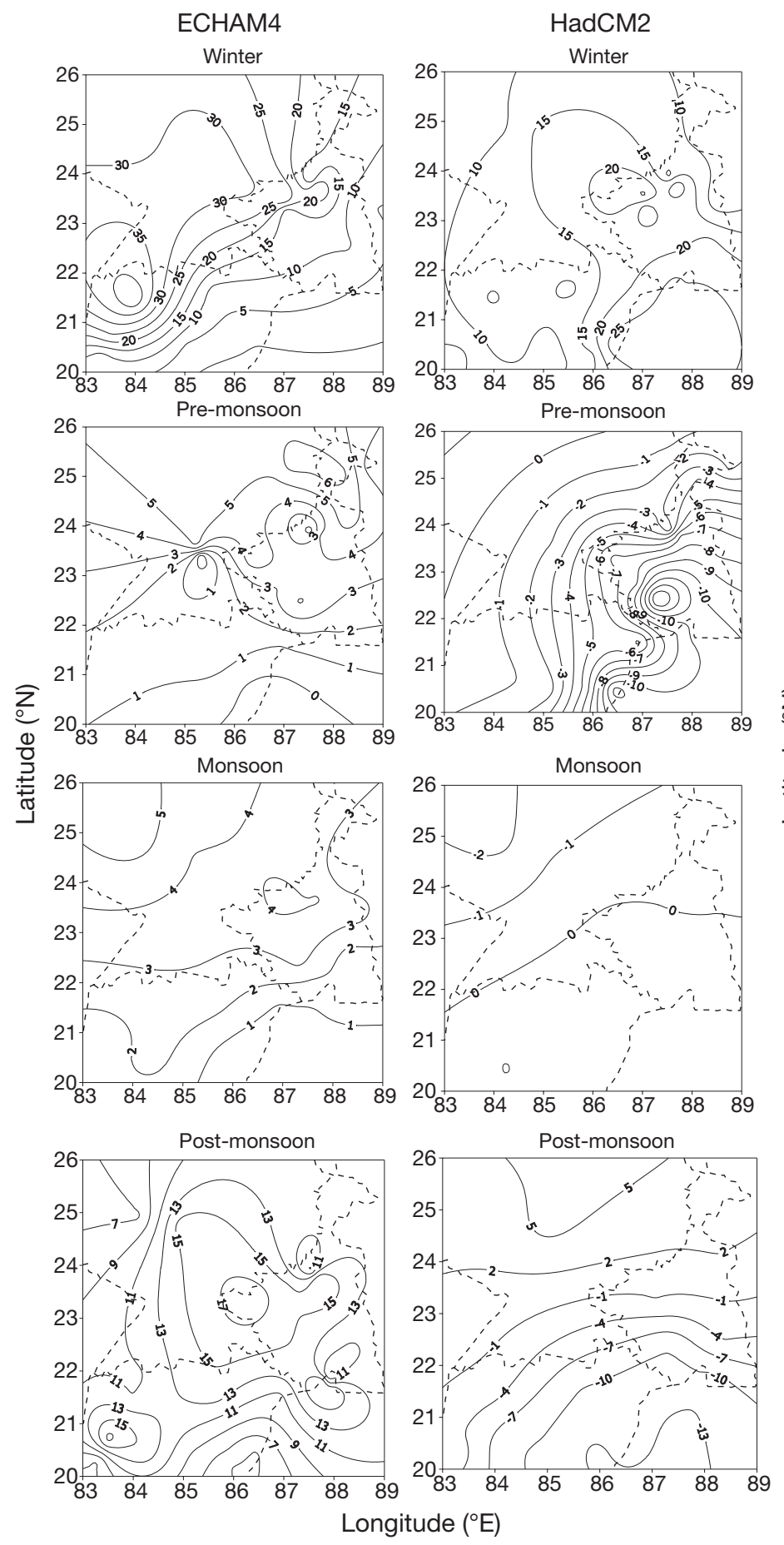

Fig. 7. Scenarios showing seasonal rainfall change (\%) in the study region for the period 2010-2039 with respect to the 1961-1990 baseline for ECHAM4 and HadCM2
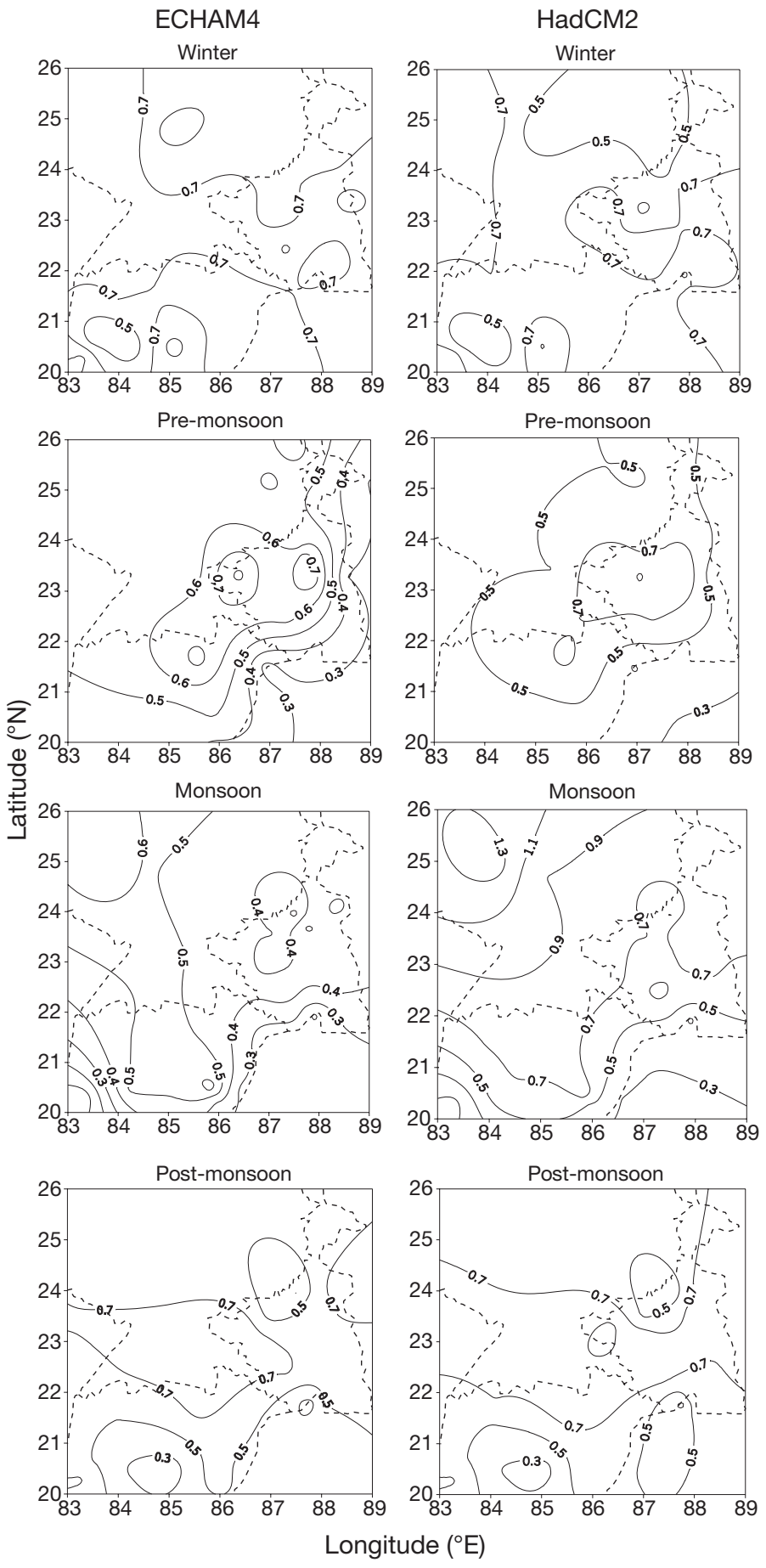

Fig. 8. Scenarios showing seasonal temperature change $\left({ }^{\circ} \mathrm{C}\right)$ in the study region for the period 2010-2039 with respect to the 1961-1990 baseline for ECHAM4 and HadCM2 
$1.1^{\circ} \mathrm{C}$ with a positive gradient from the sea inland. ECHAM4 also shows a similar gradient, though the changes are less. HadCM2, characteristically, shows less change in the post-monsoon season with a maximum of $0.7^{\circ} \mathrm{C}$ while ECHAM4 shows a similar maxi-

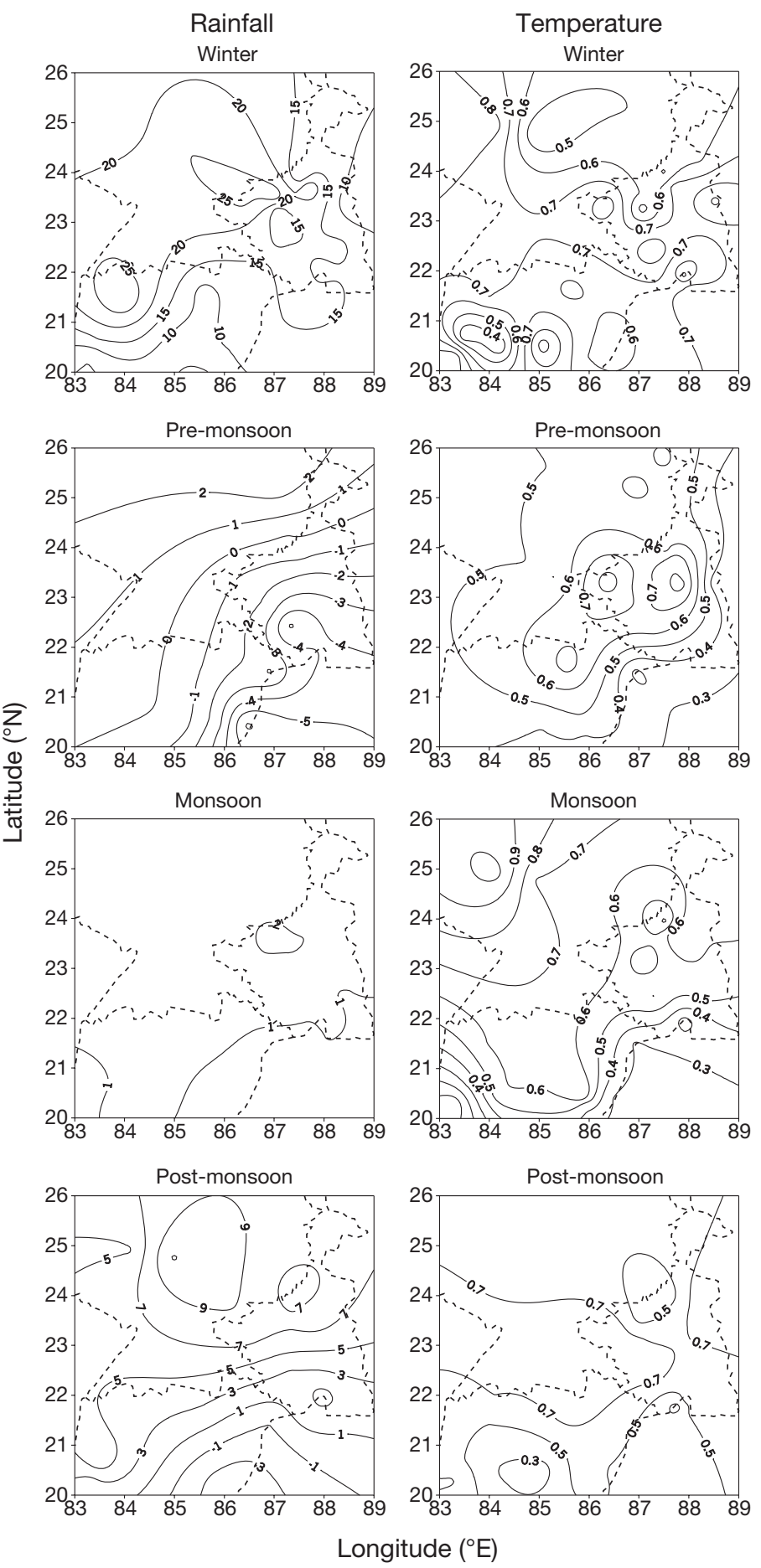

Fig. 9. Seasonal composite scenarios of rainfall change (\%) and temperature change $\left({ }^{\circ} \mathrm{C}\right)$ for $2010-2039$ with respect to the 1961-1990 baseline mum of $0.7^{\circ} \mathrm{C}$, though both the models indicate a similar gradient, from a minimum over the SW to a maximum over the NW part of the study area.

\subsection{Composite scenarios for 2010-2039}

Since - as stated elsewhere - no single GCM can be identified as being consistently better at simulating current and future climate change scenarios, composite scenarios (similar to that in Section 3) have been developed using HadCM2 and ECHAM4 for the best estimation for impact analysts.

\subsubsection{Composite rainfall scenarios}

The combined rainfall change for the winter season is higher (10 to $25 \%$ ) in the study region (Fig. 9). The pre-monsoon season indicate a dipole-type structure, with a positive value of $2 \%$ in inland and negative changes $(-5 \%)$ over the coast. Again, the monsoon season rainfall change is strikingly lower compared to the other seasons ( 1 to $2 \%$ ). Most of the study area is likely to experience positive changes in the post-monsoon season with one exception over a part of the coastal area.

\subsubsection{Composite temperature scenarios}

The composite projected seasonal temperature change scenarios over the study region are shown in Fig. 9. Warming is greatest in the winter season, with a large part of the study area expected to have warming greater than $0.7^{\circ} \mathrm{C}$. In the pre-monsoon and post-monsoon seasons, pockets of higher warming are expected off the coast, while the monsoon season reveals a gradient in warming from the lowest value over the coast to a higher value inland.

\section{DISCUSSION AND CONCLUSIONS}

Seasonal composite scenarios for mean surface air temperature and rainfall for the period 2010-2039 were developed for the Indian region using the 5 GCMs. These indicate a warming all over the Indian region by about 0.3 to $0.6 \pm 0.2^{\circ} \mathrm{C}$. The spatial pattern reveals that the warming is more in northern India and less in southern India, which is consistent with the IPCC report (IPCC 2001) and the findings of Rupa Kumar et al. (2002). However, pockets of negative as well as positive changes in rainfall are seen in different parts of the country irrespective of the seasons. Posi- 
tive changes in rainfall have been noticed all over the Indian region in the monsoon season, with a maximum of $2 \%$ over central India, while the post-monsoon season follows a similar pattern to the monsoon season, albeit with a variation of -2 to $+2 \%$. Exceptional variation $(15 \%)$ has been noticed in the western part of the country in the pre-monsoon season, due to lower rainfall, and percentage variation is high as a result. It is noteworthy that the upper limit indicates positive changes in rainfall, and the lower limit indicates negative changes, irrespective of the seasons. Scenarios also reveal a warming of $0.4 \pm 0.2^{\circ} \mathrm{C}$ over $\mathrm{GWB}$ and surrounding regions, where statistical downscaling was carried out to construct sub-grid scale scenarios. Rainfall changes are limited to a maximum of $4 \%$ in all the seasons.

The ability of these 5 GCMs to represent the spatiotemporal variation of rainfall and temperature over GWB and surrounding regions was verified through a comparison of model values with observations. It is noticed that all the models are unable to represent a seasonal cycle of rainfall effectively. ECHAM4 appears to be more effective in comparison to the other models for the region of interest. Again, in the case of temperature, there are considerable differences in the winter and pre-monsoon seasons, though the models represent the monsoon season more realistically, except for GFDL. The influence of the passage of western disturbances over northern India in winter and the mesoscale convective activities in the pre-monsoon season (Lohar \& Pal 1995) are unlikely to be represented in GCMs. The Student's $t$-test, using the model output and observed seasonal rainfall, also indicates that the HadCM2 and ECHAM4 are more effective than the other GCMs over GWB and surrounding regions. The ability of the models to represent the spatial patterns was also checked using spatial correlation coefficients. In general correlation coefficients are higher in the case of temperature than that of rainfall. Except in the monsoon season, low correlation coefficient values indicate that the models fail to simulate spatial patterns effectively, consistent with the findings of Hulme et al. (1994).

Construction of sub-grid scale scenarios for the mean temperature and rainfall through statistical downscaling reveals that the projected mean temperature is far more than the case when the GCM output is directly interpolated. HadCM2 indicates a warming of 0.3 to $1.3^{\circ} \mathrm{C}$ while ECHAM4 shows a warming of 0.3 to $0.7^{\circ} \mathrm{C}$. The former also indicates a reduction in rainfall in some pockets for different seasons while the latter shows an excess of rainfall in all the seasons. Composite seasonal scenarios based on these 2 models reveal a warming $\left(0.3\right.$ to $\left.0.9^{\circ} \mathrm{C}\right)$, which is higher than the projection derived directly from the GCM output over
GWB and surrounding regions. In general, an increase in rainfall is estimated in all the seasons except for the pre-monsoon season. Rainfall scenarios indicate a variation of -5 to $+9 \%$, except in the winter where it exceeds $20 \%$. This estimation is also higher than that of the projected changes derived directly from the GCMs.

Acknowledgements. We thank IMD and the Agriculture Department of West Bengal for providing necessary data. We also thank Dr. R. E. Benestad of NMI, Oslo, Norway, and anonymous reviewers, for their valuable suggestions for improving the manuscript. L.D. acknowledges the authority of Bidhan Chandra Krishi Viswavidyala, West Bengal, for approving a period of study leave during which the work was carried out.

\section{LITERATURE CITED}

Benestad RE (2002) Empirically downscaled multimodel ensemble temperature and precipitation scenarios for Norway. J Clim 15:3008-3027

Chakraborty B, Lal M (1994) Monsoon climate and its change in a doubled CO2 atmosphere simulated by CSIRO9 model. Terr Atmos Oceanic Sci 5:515-536

Crane RG, Hewitson BC (1998) Double $\mathrm{CO}_{2}$ precipitation changes for the Susquhanna Basin: downscaling from the GENESIS General Circulation Model. Int J Climatol 18: 65-76

Dong B, Valdes PJ, Hall NMJ (1996) The changes of monsoon climates due to earth's orbital perturbations and ice age boundary conditions. Palaeoclim: Data Model 1:203-240

Grotch S, MacCracken M (1991) The use of General Circulation Models to predict regional climate change. J Clim 4: 286-303

Hirakuchi H, Giorgi F (1995) Multiyear present day and $2 \times$ $\mathrm{CO}_{2}$ simulations of monsoon climate over eastern Asia and Japan with a regional climate model nested in a general circulation model. J Geophys Res 100:21105-21125

Hulme M, Zhao Z, Jiang T (1994) Recent and future climate change in East Asia. Int J Climatol 14:637-658

Huth R, Kysely J (2000) Constructing site specific climate change scenarios on a monthly scale using statistical downscaling. Theor Appl Clim 66:13-27

IPCC (2001) Climate change 2001: science of climate change. Intergovernmental Panel on Climate Change (IPCC). Cambridge University Press, Cambridge

Johns TC, Carnell CE, Crossley JF, Gregory JM, Mitchell JFB, Senior CA, Tett SFB, Wood RA (1997) The second Hadley Centre coupled ocean-atmosphere GCM: model description, spinup and validation. Clim Dyn 13:103-134

Kidson JW, Thompson CS (1998) A comparison of statistical and model-based downscaling techniques for estimating local climate variation. J Clim 11:735-753

Kim JW, Chang JT, Baker NL, Wilks DS, Gates WL (1984) The statistical problem of climate inversion: determination of relationship between local and large-scale climate. Mon Weather Rev 112:2069-77

Kripalani RH, Kulkarni A, Sabade SS, Khandekar ML (2003) Indian Monsoon variability in a global warming scenario. Nat Haz 29:189-206

Lal M, Cubasch U, Santer BD (1994) Effect of global warming on Indian monsoon simulated with a coupled oceanatmosphere general circulation model. Curr Sci (Banga- 
lore) 66:430-438

Lohar D, Pal B (1995) The effect of irrigation on premonsoon season precipitation over south West Bengal, India. J Clim 8:2567-2570

Mearns LO, Rosenzweig C, Goldberg R (1997) Mean and variance change in climate secnarios: methods, agricultural applications, and measure of uncertainty. Clim Change 35:367-396

Mooley DA, Parthasarathy B (1984) Fluctuation of all India summer monsoon rainfall during 1871-1978. Clim Change 6:287-301

Murphy J (1998) An Evaluation of statistical and dynamical techniques for downscaling local climate. J Clim 12: 2256-2284

Palutikof JP, Wigley TML (1996) Developing climate change scenarios for the Mediterranean Region. In: Jeftic L, Keckes S, Pernetta JC (eds) Climate change and the Mediterranean: environmental and societal impacts of climate change and sea level rise in the Mediterranean, Vol 2. Edward Arnold, London, p 27-56

Palutikof JP, Guo X, Wigley TML, Gregory JM (1992) Regional changes in climate in the Mediterranean Basin due to global greenhouse warming. Mediterranean Action Plan Tech Rep Ser 66, UNEP, Athens

Robinson PJ, Finkelstein PL (1991) The development of impact oriented climate change scenarios. Bull Am Mete-

Editorial responsibility: Otto Kinne,

Oldendorf/Luhe, Germany orol Soc 72:481-490

Rupa Kumar K, Pant GB, Parthasarathy B, Sontakke A (1992) Spatial and sub-seasonal patterns of long-term trends of India summer monsoon rainfall. Int J Climatol 12:257-268

Rupa Kumar K, Kumar KK, Ashrit RG, Patwardhan SK, Pant GB (2002) Climate change in India: observations and model projections. In: Shukla PR, Sharma SK, Ramana PV (eds) Climate change and India: issues, concerns and opportunities. Tata McGraw-Hill, New Delhi, p 24-75

Sadhukhan I, Lohar D, Pal DK (2000) Premonsoon season rainfall variability over Gangetic West Bengal and its neighbourhood, India. Int J Climatol 20:1485-1493

von Storch H, Zorita E, Cubash U (1993) Downscaling of global climate change estimating to regional scale: an application to Iberain rainfall in wintertime. J Clim 6: 1161-1171

Wigley TML, Jones PD, Briffa KR, Smith G (1990) Obtaining sub-grid scale information from coarse-resolution General Circulation Model output. J Geophys Res 95:1943-1953

Wilby RL, Wigley TML (1997) Downscale general circulation model output: a review of methods and limitations. Prog Phys Geogr 21:530-548

Wilby RL, Wigley TML, Conway D, Jones PD, Hewitson BC, Main J, Wilks DS (1998) Statistical downscaling of general circulation model output: A comparison of methods. Water Resour Res 4:2995-3008

Submitted: September 6, 2004; Accepted: November 1, 2005 Proofs received from author(s): November 22, 2005 